\title{
THE ROLE OF CUSTOMER SATISFACTION AS MEDIATION ON THE INFLUENCE OF SERVICE PERFORMANCE AND RELATIONSHIP MARKETING ON CUSTOMER LOYALTY
}

\author{
I Gusti Ayu Imbayani \\ Mahasaraswati University Denpasar, Bali, Indonesia \\ Pande Ketut Ribek \\ Mahasaraswati University Denpasar Bali, Indonesia \\ Ni Putu Yeni Astiti \\ Mahasaraswati University Denpasar Bali, Indonesia \\ DOI: 10.31364/SCIRJ/v9.i07.2021.P0721870 \\ http://dx.doi.org/10.31364/SCIRJ/v9.i07.2021.P0721870
}

\begin{abstract}
Every company can achieve competitive advantage through long-term relationships between companies and customers to build customer loyalty. Competitive advantage can be formed through various factors. This study aims to determine the effect of Service Performance and Relationship Marketing on Customer Loyalty mediated by Customer Satisfaction. The method used in this study is a quantitative method, the population in this study was 95 people using PLS analysis techniques. Based on the results of the analysis, it is found that service performance has an influence on customer satisfaction, relationship marketing has no effect on customer satisfaction, service performance has an influence on customer loyalty, relationship marketing has an influence on customers, customer satisfaction has an influence on customer loyalty, customer satisfaction is a mediating variable. partial (partial) on the effect of service performance and relationship marketing on customer loyalty. This research is expected to help companies in increasing customer loyalty through service performance and relationship marketing.
\end{abstract}

Keywords: Service performance, Relationship marketing, Customer loyalty, Customer satisfaction

\section{INTRODUCTION}

Every company strives to have an advantage and survive in any situation. The competitive situation in the banking business in this millennium is getting tougher, so that a company that can survive is a company that has the ability to continuously increase customer loyalty, which is the key to the company's competitive advantage. Entering the new millennium, the dimensions of customer satisfaction, efficiency, market research, customer loyalty must be the focus of the company's attention. Every company can achieve competitive advantage through long-term relationships between companies and customers by building customer loyalty.

Loyal customers can be caused because the person concerned is satisfied with the services provided. If the customer is not satisfied, it can cause the customer to switch to another product. Some of the advantages obtained if the company has loyal customers is that it can reduce marketing costs because the cost of attracting new customers is more expensive. Good service quality in a company will create satisfaction for its customers.

Customers are satisfied with the services or products they receive customers will compare the services provided with other companies or service providers. If customers feel really satisfied, they will repurchase and recommend others to buy at the same place. Therefore, the company must start thinking about the importance of customer service more maturely through service quality, because it is now increasing recognized that service is an important aspect in order to survive in business and win the competition (Koestanto, 2014:27).

Success in competition in the banking world will be fulfilled by creating customer satisfaction and loyalty. Customer satisfaction and loyalty is obtained if the company changes its point of view from being product and service oriented to being customer oriented. This view should also apply to banking companies and the strategy used is to build customer loyalty. Every bank must have a strategy to create customer satisfaction and loyalty to increase competitiveness in the banking world. One strategy that can be applied to create customer satisfaction and loyalty is to build relationships between banks and customers or better known as Relationship marketing. 
Customer satisfaction is created from the services provided by the bank. According to Kotler \& Keller (2009:138) satisfaction is a person's feelings of pleasure or disappointment arising from comparing the perceived performance of the product or result against expectations them. Loyalty is a customer's deep commitment to re-subscribe or re-purchase a product or service that will arrive, even though the influence of the situation and marketing efforts have the potential to cause behavior change. Customers who are satisfied with the services and services of the bank will return and repeat the use of these services. Satisfied customers will be loyal to the bank which will certainly provide many benefits for the bank, for example to attract new customers. Based on the description above, it can be seen that relationship marketing,

One of the banking companies in Indonesia that implements relationship marketing to build relationships with customers is PT. Bank Central Asia Tbk. or commonly abbreviated as BCA. BCA is very dominant in the products that are issued. BCA just isn't in the top position in mortgage products and leasing financing. Of course, for this, customers already have the products they like, such as BTN in Indonesia activity KPR and Adira finance in leasing activities. Of course, to be able to lead in all lines of banking products, BCA must be able to meet consumer satisfaction where currently BCA is famous for products that provide loan interest rates for credit, credit cards and other financing which are quite high compared to other products. Competitors so customers should think twice about using BCA products. in addition,

BCA was able to obtain an increase in profit from year to year. Even with credit interest that can be said to be the highest compared to other but with increasing profits that can be generated every year. It can be said that BCA has loyal customers who use the products issued by the banking sector. Nevertheless, BCA cannot be separated from several villages starting from the quality of service and relationships with consumers.

From initial observations, it is known that in terms of service quality, BCA is one of the leaders in the banking industry. However, due to the large number of customers they have, the value of reliability from BCA employees becomes questionable because it often happens queue long and customers are waiting too long to be served. This certainly reduces the satisfaction of these customers and it is not impossible to burden loyalty to the company. In terms of relationship marketing, BCA has good communication and commitment with customers and customers. However, the complaint is because the bank is considered to be less flexible in handling conflicts such as the problem of delays that are only one day which is still subject to a maximum fine even though the delay has been informed long ago by the customer and customer .

Based on the background of the existing problems, the author feels interested in raising the title The Role of Customer Satisfaction As Mediation On the Effect of Service Performance and Relationship Marketing on Customer Loyalty

Based on the description of the background of the problem that has been explained, the main problem studied in this study is "Does Customer Satisfaction Play a Mediating Role on the Effect of Service Performance and Relationship Marketing on Customer Loyalty at PT. Bank Central Asia In Denpasar?
Based on the explanation of the background and the subject matter above, the purpose of this research is to find out and analyze the role of customer satisfaction as a mediation on the influence of service performance and relationship marketing on customer loyalty.at PT. Bank Central Asia in Denpasar?"

\section{LITERATURE REVIEW}

\section{Service Performance on Customer Satisfaction}

Service quality provides an impetus to customers or in this case visitors to establish strong ties with institutions or agencies providing services. This good relationship bond will enable service institutions to understand carefully the expectations of customers/visitors and their needs. Thus, service providers can increase visitor satisfaction by maximizing a pleasant visitor experience and minimizing an unpleasant visitor experience. If the service received or perceived is in accordance with customer expectations, then the quality received or perceived is in accordance with customer expectations, then service quality is perceived as ideal quality. but conversely if the service received or perceived is lower than expected then the perceived service quality is low . Kotler (2012:35) consumer satisfaction is the level of a person's feelings after comparing the perceived performance or results compared to his expectations. Gong \& Yi (2018); Neupane \& Devkota (2017); Khoo \& McGregor (2017); Saleem \& Raja (2014) Dam and Dam (2021); Dandiset al (2021); Amoako et al., (2019) found that service quality has a positive influence on customer satisfaction, as well as the research of Farooq., et al. 2020 found that service quality has a positive effect on Malaysia Airline customer satisfaction.

\section{Relationship Marketing Effect Against Customer Satisfaction}

Companies that do not only focus on selling their products but also pay attention to the relationship that arises between consumers and companies will provide added value to the company. Satisfied consumers will find it easy to establish good relations with the company. Evan and Laskin (2004:11) argue that "A key goal of relationship marketing is to improve customer satisfaction. Research conducted by Lusiah \& Noviantoro (2018); Ayu (2019) Santouridis \& Veraki (2017); Ibadi (2019) shows that relationship marketing has an influence on consumer satisfaction. Caliskan \& Esmer (2020); Windiari \& Djumarno (2021); Saputro et al., (2020) found that relationship marketing can have a positive impact on customer satisfaction.

\section{Influence of Service Performance on Customer Loyalty}

If the quality of service provided by the company is in line with expectations and performance, consumers will be happy because the expectations and performance of the service are good and consumer loyalty will directly arise in the company. According to the results of research conducted by Slack \& Singh (2020); Khoo \& McGregor (2017); Dam \& Dam (2021); Dandis et al., (2021) stated that service quality has an influence on customer loyalty. Another study conducted by Jaka (2018) stated that good service quality can spur one's loyalty

The Effect of Relationship Marketing on Customer Loyalty 
To build loyal relationships, companies must make certain sacrifices, which are designed to foster customer loyalty. Activities to build customer loyalty (keep and win customers) by providing value for all parties involved in the relational exchange. Ndubisi (2004:21) states that "has suggested that companies should make sacrifices and worth while investments in building relationships with loyal, or at least potentially loyal customers". Anggrahita (2018); Gery (2018) Caliskan \& Esmer (2020); Banna \& Rahman (2020); Windiari \& Djumarno (2021); Khan et al., (2020); Saputro et al., (2020) found that relationship marketing can have a positive impact on consumer loyalty.

\section{The Effect of Customer Satisfaction on Customer Loyalty}

The best approach to retain customers is to provide the highest level of satisfaction and value to customers which will result in loyal customers. The satisfaction felt by consumers in using or consuming products or services will have implications for loyal attitudes to products or services that are felt to meet their expectations. Kotler and Armstrong (2006), stated that "And a best approach to customer retention is to deliver high customer satisfaction and value that results in customer loyalty. Khoo \& McGregor (2017); Saleem \& Raja (2014); Leninkumar (2017); Kandampully \& Suhartanto (2000); Haryono (2016); Dam \& Dam (2021) found that customer satisfaction has a positive effect on consumer loyalty.

\section{Customer satisfaction mediates the effect of service performance on customer loyalty}

Quality has a close relationship with customer satisfaction in determining consumer loyalty. Quality provides an impetus to customers to establish a strong relationship with the company. In the long term this kind of bond allows the company to understand carefully the customer's expectations and their needs. Thus, companies can increase customer satisfaction through the provision of pleasant services, which will certainly create high consumer loyalty to the company. Companies can increase customer satisfaction through the provision of pleasant services will certainly create high consumer loyalty to the company, (Tjiptono, 2011). customers feel that quality and satisfaction affect loyalty (Özkan et al., 2019; Khoo \& McGregor (2017); Leninkumar (2017). Kumar (2017) finds satisfaction as a mediator between quality (empathy) and loyalty. From research conducted by Ngo \& Nguyen (2016); Dandis, Ala'Omar et al., (2021) found satisfaction as a mediator between quality and loyalty. Previous research on the effect of service quality on loyalty mediated by customer satisfaction conducted by Puspitsari and Edris (2011), showed that service quality had an effect on loyalty mediated by patient satisfaction.

\section{Customer satisfaction mediates the influence of relationship marketing on customer loyalty}

Relationship marketing is an attitude to maintain relationships with consumers. This strategy is used so that consumers do not switch to other brands or companies. Tse and Wilton define customer satisfaction or dissatisfaction as the customer's response to the evaluation of the perceived discrepancy between initial expectations before purchase and the actual performance of the product prepared after use or consumption of the product in question. Kotler and Armstrong (2004:13) Relationship marketing is the process of creating, maintaining, and strengthening strong and value-laden relationships with customers and trustees. This strong relationship will create satisfaction so that consumers will be loyal to the company. This is in line with the research of Khan, Rizwan Ullah et al., (2020); Saputro et al., (2020);

Hypothesis

H1 : Service performance has a positive effect on customer satisfaction at PT. Bank Central Asia In Denpasar.

H2 :Relationship marketing positive effect on customer satisfaction on customers of PT. Bank Central Asia In Denpasar.

H3 : Service performance has a positive effect on customer loyalty to customers of PT. Bank Central Asia In Denpasar.

H4 : Relationship marketing has a positive effect on customer loyalty to customers of PT. Bank Central Asia In Denpasar.

H5 : Customer satisfaction positive effect on customer loyalty to customers of PT. Bank Central Asia In Denpasar.

H6 : Customer satisfaction able to mediate the effect of service performance on customer loyalty to customers of PT. Bank Central Asia In Denpasar.

H7 : Customer satisfaction able to mediate the influence of Relationship marketing on Customer loyalty at PT. Bank Central Asia In Denpasar

\section{RESEARCH METHODS}

The place of this research was carried out in Denpasar City which focused on customers of PT. Bank Central Asia In Denpasar. Technique determination deep sample research. This is done purposive sampling(total sample 95 people). This Research Uses types of quantitative and qualitative data and primary source and secondary. The data collection methods used in this study were observation, interviews and questionnaires as well as documentation data in the form of company history and library data, as well as for the analytical method using inferential analysis.

\section{RESULTS AND DISCUSSION}

\section{Evaluation Outer Model (Measurement Model)}

Convergent Validity. All indicators reflecting each construct have an outer loading value $>0.60$ and significant at the 0.05 level, all indicators are valid. Discriminant Validity. The AVE value of all constructs $>0.50$ so that it meets the valid requirements based on the discriminant validity criteria. Composite Reliability and Cronbach Alpha. the value of composite reliability and Cronbach Alpha of all constructs has shown a value greater than 0.70 so that it meets the reliable requirements based on the composite reliability criteria. 
The effect of mediation analyzed includes the analysis of direct and indirect effects.

Table 2

The results of direct and indirect effects

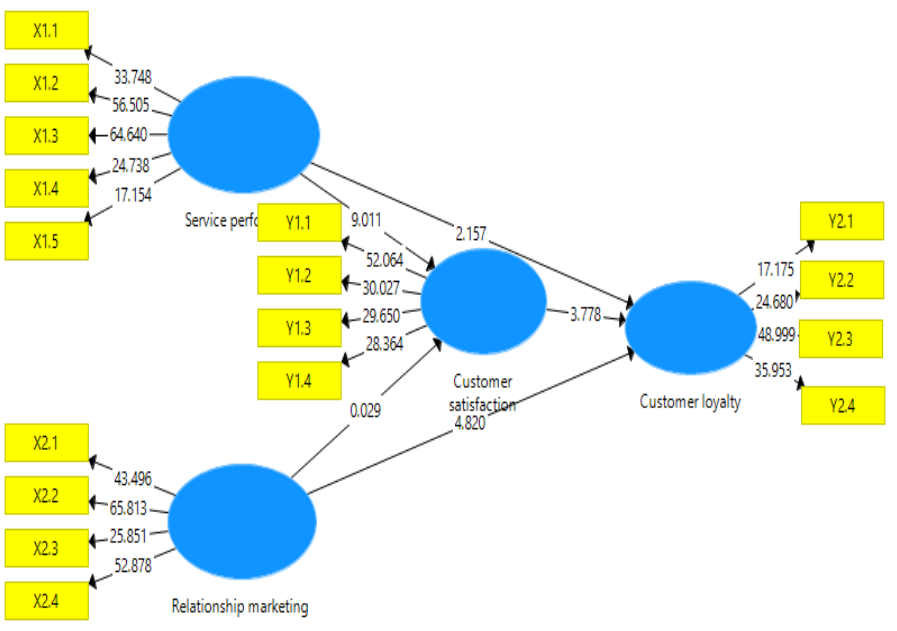

Figure 1

Bootstrapping Model

\section{Inferential Analysis Test \\ Path Hypothesis Analysis and Testing}

Table 1

Path coefficient and statistical test

\begin{tabular}{|c|c|c|c|c|c|c|}
\hline CONSTRUCT & $\begin{array}{c}\text { Original } \\
\text { Sample (0) }\end{array}$ & $\begin{array}{c}\text { Sample } \\
\text { Mean (M) }\end{array}$ & $\begin{array}{c}\text { Standard } \\
\text { Error (STERR) }\end{array}$ & $\begin{array}{c}\text { TStatistics } \\
\text { (|O/STERR|) }\end{array}$ & $P$ Values & Information \\
\hline $\begin{array}{l}\text { VICE PERFORMANCE } \rightarrow> \\
\text { TTOMER SATISFACTION }\end{array}$ & 0.796 & 0.794 & 0.088 & 9.011 & 0.000 & Significant \\
\hline $\begin{array}{l}\text { ERVICE PERFORMANCE -> } \\
\text { USTOMER LOYALTY }\end{array}$ & 0.216 & 0.233 & 0.100 & 2.157 & 0.031 & Significant \\
\hline $\begin{array}{l}\text { ELATIONSHIP } \\
\qquad \begin{array}{l}\text { MARKETING } \\
\text { CUSTOMER }\end{array} \\
\text { ATISFACTION }\end{array}$ & -0.003 & 0.00 & 0.107 & 0.029 & 0.977 & $\begin{array}{c}\text { Not } \\
\text { Significant }\end{array}$ \\
\hline $\begin{array}{l}\text { ELATIONSHIP MARKETING } \\
\text { CUSTOMER LOYALTY }\end{array}$ & 0.412 & 0.411 & 0.085 & 4.820 & 0.000 & Significant \\
\hline $\begin{array}{l}\text { USTOMER SATISFACTION } \\
\text { CUSTOMER LOYALTY }\end{array}$ & 0.342 & 0.336 & 0.090 & 3.778 & 0.000 & Significant \\
\hline
\end{tabular}

Source: Data processed, 2021

Based on Table 1, Service performance has a positive effect of 0.796 on customer satisfaction, and the relationship is significant at the 0.05 level, because the t-statistic value is greater than 1.96, which is 9.011. Service performance has a positive effect of 0.216 on customer loyalty, and the relationship is significant at the 0.05 level, because the $\mathrm{t}$ statistic value is greater than 1.96 , which is 2.157 . Relationship marketing has a negative effect of -0.003 on customer satisfaction, and the relationship is not significant at the 0.05 level, because the t-statistic value is smaller than 1.96 , which is 0.029 . Relationship marketing has a positive effect of 0.412 on customer loyalty, and the relationship is significant at the 0.05 level, because the t-statistic value is greater than 1.96, which is 4.820 .

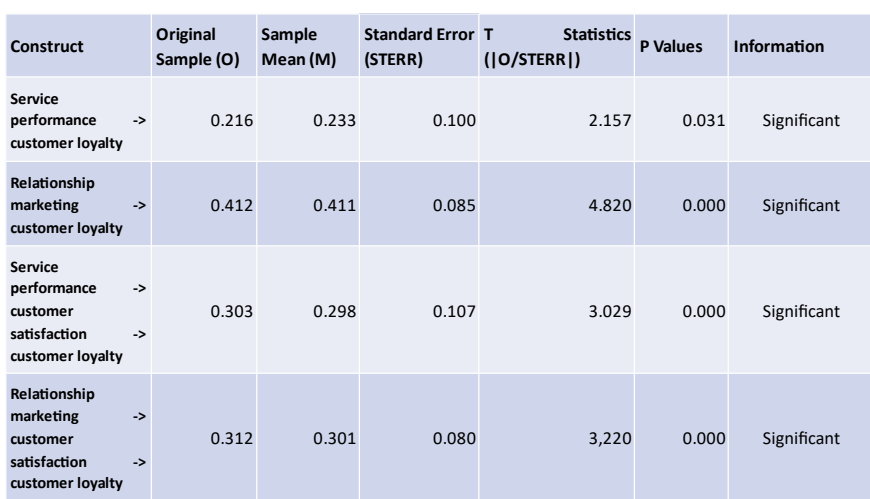

Source: Data processed, 2021

Relationship live service performance $\rightarrow$ customer loyalty shows significant results and an indirect relationship with service performance $\rightarrow$ customer satisfaction $\rightarrow$ customer loyalty also shows significant results, which means that based on the criteria for customer satisfaction, it is a partial mediation between service performance and customer loyalty.

Direct relationship marketing relationship $\rightarrow$ customer loyalty show significant results and indirect relationship marketing $\rightarrow$ customer satisfaction $\rightarrow$ customer loyalty also shows significant results, which means that based on the criteria for customer satisfaction, it is a partial mediation between service performance and customer loyalty.

\section{Discussion}

\section{The Influence of Service Performance on Customer Satisfaction}

The results of data analysis show that service performance as a positive effect of 0.796 on customer satisfaction, and the relationship is significant at the 0.05 level because the $\mathrm{P}$ Values is 0.000 . And the t-statistic value is 9.011. service performance has a positive and significant influence on customer satisfaction. The results of the analysis mean that the higher the service performance, the higher the customer satisfaction. With good service quality, consumers will get more value than what they are actually looking for so that it will lead to satisfaction in consumers. The results of this study are generally able to answer. Pre-existing hypotheses including research conducted by Sisca (2019) found that good service quality will be able to grow consumer satisfaction.

\section{The Effect of Relationship Marketing on Customer Satisfaction}

The results of data analysis show data relationship marketing has a negative effect of -0.003 on customer satisfaction, and the relationship is not significant at the 0.05 level, because the $\mathrm{P}$ value is 0.977 and the $\mathrm{t}$-statistic value is smaller than 1.96 , which is 0.029 . Relationship marketing has no effect on customer satisfaction. The results of the analysis have the meaning that whatever happens to relationship marketing will not change the condition of customer satisfaction. This may happen because not all consumers are 
concerned with the closer relationship that exists with the Bank, but only assess Bank BCA from the benefits they provide.

\section{Effect of Service Performance on Customer Loyalty}

The results of data analysis show that service performance has a positive effect of 0.216 on customer loyalty, and the relationship is significant at the 0.05 level, because the $P$ value is 0.031 and the t-statistic value is greater than 1.96 , which is 2.157. Service performance has a positive and significant effect on customer loyalty. The results of the analysis have the meaning that the higher the service performance, the higher the customer loyalty. Where with good service consumers will feel it will not be easy to get similar services elsewhere so they feel more loyal because of the treatment they are getting at this time. These results are in line with the results of research conducted by Iwan (2019) stating that service quality has an influence on customer loyalty.

\section{The Effect of Relationship Marketing on Customer Loyalty}

The results of data analysis show that relationship marketing has a positive effect of 0.412 on customer loyalty, and the relationship is significant at the 0.05 level, because the $P$ value is 0.000 and the $t$-statistic is greater than 1.96 , which is 4.820. Relationship marketing has a positive and significant influence on customer loyalty. The results of the analysis have the meaning that the increasing relationship marketing, the more customer loyalty will also increase. The relationship that exists between consumers and the Bank will make consumers have closeness not only as product providers and product users but also a sense of loyalty in the banking activities carried out. This research is in line with research conducted by Anggrahita (2018) which shows that relationship marketing has an influence on consumer loyalty. In line with research conducted by Gery (2018), it also states that relationship marketing has an influence on consumer loyalty.

\section{The Effect of Customer Satisfaction on Customer Loyalty}

The results of data analysis show that customer satisfaction has a positive effect of 0.342 on customer loyalty, and the relationship is significant at the 0.05 level, because the $\mathrm{P}$ value is 0.000 and the $\mathrm{t}$-statistic is greater than 1.96, which is 3.778. Customer satisfaction has a positive and significant influence on customer loyalty. The results of the analysis have the meaning that the more customer satisfaction increases, the more customer loyalty increases. Consumers who are satisfied with what they get will make that satisfaction into a loyalty because consumers think that they will not necessarily get the same satisfaction elsewhere. This is in line with research conducted by Espejel (2007) in Haryono (2016) finding that consumer satisfaction has a positive and significant effect on consumer loyalty.

\section{Customer satisfaction mediates the effect of service} performance on customer loyalty.

Analysis of the role of mediation through the examination method in this study on the construct customer satisfactionon the relationship between service performance and customer loyalty found that customer satisfaction is a partial mediating variable because the results of data processing show that the value of the mediating variable (customer satisfaction) has a significant effect on the same as other variables so that it can be said in this case customer satisfaction is a partial mediating variable. These results indicate that service performance can encourage increased customer loyalty with the help of customer satisfaction. Consumers who are satisfied with the services provided will be able to foster loyalty. This is in line with research conducted by Puspitasari and Edris (2011), showing that service quality affects loyalty mediated by patient satisfaction.

Customer satisfaction mediates the influence of relationship marketing on customer loyalty

Analysis of the role of mediation through the examination method in this study of the customer satisfaction construct on the relationship between relationship marketing and customer loyalty found that customer satisfaction is a partial mediating variable because the results of data processing show that the value of the mediating variable (customer satisfaction) has a significant influence. the same as other variables so that it can be said in this case customer satisfaction is a partially mediating variable. These results indicate that relationship marketing can encourage increased customer loyalty with the help of customer satisfaction. Consumers who are satisfied with the services provided will be able to foster loyalty. This is in line with Putri' s research (2014) that customer satisfaction mediates the relationship between relationship marketing and customer loyalty. The more satisfied consumers are with the company's products and services, the stronger the loyalty bonds that consumers have to the company will be.

\section{CONCLUSIONS AND SUGGESTIONS}

\section{Conclusions}

Based on the results, it can be concluded that service performance has a positive and significant effect on customer satisfaction at PT. Bank Central Asia In Denpasar. This means that the increasing service performance of PT. Bank Central Asia In Denpasar, the customer satisfaction felt by PT. Bank Central Asia Tbk KCP. Relationship marketing does not have a positive and significant impact on customer satisfaction at PT. Bank Central Asia In Denpasar. The results mean that relationship marketing has no effect on customer satisfaction at PT. Bank Central Asia In Denpasar. Service performance positive and significant effect on customer loyalty to customers of PT. Bank Central Asia In Denpasar. This means that the increasing service performance of PT. Bank Central Asia In Denpasar, the customer loyalty of PT. Bank Central Asia Tbk KCP. Relationship marketing positive and significant effect on customer loyalty to customers of PT. Bank Central Asia In Denpasar. This means that the increasing relationship marketing from PT. Bank Central Asia In Denpasar, the customer loyalty of PT. Bank Central Asia Tbk KCP. Customer satisfaction positive and significant effect on customer loyalty to customers of PT. Bank Central Asia In Denpasar. This means that the increasing customer satisfaction from customers of PT. Bank Central Asia In Denpasar, the customer loyalty of PT. Bank Central Asia Tbk KCP. Customer satisfaction positive and significant effect on customer loyalty to customers of PT. Bank Central Asia In Denpasar. This means that the increasing customer satisfaction from customers of PT. Bank 
Central Asia In Denpasar, the customer loyalty of PT. Bank Central Asia Tbk KCP. Customer satisfaction positive and significant effect on customer loyalty to customers of PT. Bank Central Asia In Denpasar. This means that the increasing customer satisfaction from customers of PT. Bank Central Asia In Denpasar, the customer loyalty of PT. Bank Central Asia Tbk KCP.

Customer satisfaction is a partial mediation variable (partial) on the effect of Service performance on Customer loyalty to customers of PT. Bank Central Asia In Denpasar. This means that service performance can encourage increased customer loyalty with the help of customer satisfaction. Customer satisfaction is a partial mediation variable on the influence of relationship marketing on customer loyalty to PT. Bank Central Asia In Denpasar. This means that relationship marketing can encourage increased customer loyalty with the help of customer satisfaction.

\section{Suggestions}

Based on the results of the research that has been done, the writer can put forward some suggestions, namely as follows:

1. In the service performance variable, the physical quality indicator is the indicator with the lowest answer value. This means that for now the physical quality in PT. Bank Central Asia in Denpasar is considered less than optimal. This can be a reference for the management of PT. Bank Central Asia In Denpasar, the management should start paying attention to the existing physical facilities, which have not been optimal due to age. With better physical quality in the form of buildings, furniture or other facilities and infrastructure, it will increase customer comfort while at PT. Bank Central Asia In Denpasar.

2. In the relationship marketing variable, the indicator with the lowest answer is conflict handling. This means that currently the handling of existing conflicts is not optimal. This result is actually very good so that PT. Bank Central Asia in Denpasar is able to pay attention to things that are very closely related to consumers. Proper handling of conflicts will certainly get a positive response from customers and the recipient will be good. Therefore, the handling of conflicts that must be done in the future is one that still pays attention to consumer needs.

3. In the customer satisfaction variable, the indicator of completeness of information is the indicator with the lowest answer. This means that for now the completeness of the information shared by PT. Bank Central Asia in Denpasar is considered less than optimal. For this reason, it is hoped that PT. Bank Central Asia in Denpasar began to provide information about changes in banking activities directly to individual customers, not through official announcements.

4. This study only examines service performance, relationship marketing, customer satisfaction, on customer loyalty. Further researchers are expected to add other factors that affect customer loyalty such as: product quality, brand image, trust, commitment and product differentiation.

5. Limitations in this study because in this study the number of respondents was only 95 people and focused on priority customers only. This of course cannot describe the overall situation in the field. In addition, the variables used are still limited and of course there are many more variables that affect customer loyalty. In addition, due to the limited time of the study and the number of variables used, it is expected that future there are other studies that explore customer loyalty using other variables.

\section{REFERENCES}

[1] Agus Sartono. 2010. Financial Management Theory and Applications. Edition 4. Yogyakarta: BPFE

[2] Alfansi, Lizar. 2012. Financial Services Marketing. Jakarta: Salemba Empat

[3] Amoako, GK, Neequaye, EK, Tick Fighting, SG, Caesar, LD, \& Ofori, KS (2019). Relationship marketing and customer satisfaction in the Ghanaian hospitality industry: an empirical examination of trust and commitment. Journal of Hospitality and Tourism Insights.

[4] Anggrahita. 2018. "The Influence of Relationship Marketing, Customer Value, And Trust on Customer Loyalty At Pt. Asuransi Jiwasraya Malang City Branch. Journal of Business Management Volume 8 no. 02 October 2018 Edition

[5] Banna, H., \& Rahman, N. (2020). Impact of relationship marketing on customer loyalty in banking sector of UK.

[6] Caliskan, A., \& Esmer, S. (2020). An assessment of port and shipping line relationships: the value of relationship marketing. Maritime Policy \& Management, 47(2), 240257.

[7] Come on. 2019. "The Influence of Customer Relationship Management on Customer Loyalty Through Customer Satisfaction (Study on Go-Jek Customers in Padang City). Petra Journal of Marketing Management Vol. 3, No. 1, (2015) 1-9

[8] Bitner, DD Gremler. 2013. Services Marketing: Integrating Customer Focus Across the Firm. 6th ed

[9] Buchari Alma. 2007. Management Marketing and Service Marketing, Alfabeta, Bandung.

[10] Chan, Syafruddin. 2003. Relationship Marketing: Marketing Innovation That Brings Customers To Their Knees, Gramedia, Jakarta

[11] Dam, SM, \& Dam, TC (2021). Relationships between service quality, brand image, customer satisfaction, and customer loyalty. The Journal of Asian Finance, Economics and Business, 8(3), 585-593.

[12] Dandis, AO, Wright, LT, Wallace-Williams, DM, Mukattash, I., Al Haj Eid, M., \& Cai, H. (2021). Enhancing consumers' self-reported loyalty intentions in Islamic Banks: The relationship between service quality and the mediating role of customer satisfaction. Cogent Business \& Management, 8(1), 1892256. 
[13] Durianto, Darmadi. 2001. Strategy to Conquer the Market through Research. Equity and Behavior. Jakarta : PT Gramedia Pustaka

[14] Evans, Joel R and Laskin, Richard L. 2004. "The Relationship Marketing Process: A Conceptualization and Application," Industrial Marketing Management 23, 439-452.

[15] Farooq, MS, Salam, M., Fayolle, A., Jaafar, N., \& Ayupp, K. (2018). Impact of service quality on customer satisfaction in Malaysia airlines: A PLS-SEM approach. Journal of Air Transport Management, 67, 169-180

[16] Gery. 2018." Analysis of the Effect of Relationship Marketing on Customer Loyalty at Tx Travel Agents Jember.Agora Vol. 6, No. 2 (2018)

[17] Ghozali, I. Latan, H. 2012. Partial Least Square: Concepts, Techniques and Applications of SmartPLS 2.0 M3. Semarang: Diponegoro University Publishing Agency

[18] Gong, T., \& Yi, Y. (2018). The effect of service quality on customer satisfaction, loyalty, and happiness in five Asian countries. Psychology \& Marketing, 35(6), 427442.

[19] Griffin, Jill. 2003. Customer Loyalty: Growing And Retaining Customers. Erlangga Publisher. Jakarta

[20] Hurriyati, Ratih. 2013. Marketing Mix and Consumer Loyalty. Bandung: Alphabet.

[21] divine. 2019. "The Effect of Relationship Marketing on Customer Loyalty with Customer Satisfaction as an Intervening Variable at the Nada Music Store, Bandung City. e-Proceeding of Management : Vol.6, No.2 August 2019 | Page 4477

[22] Irawan. 2012. Modern Marketing Management 2nd Edition.Yogyakarta: Liberty Offset.

[23] Ivan. 2019. "The Influence of Service Quality and Emotional Closeness to Customer Loyalty". Journal of Business and Management Inspiration, Vol 2, (1), 2018, $55-64$

[24] Jaka. 2018. "Service Quality and Customer Satisfaction with Loyalty to Bank BJB. Journal of Ecodemica, Vol. 2 No. April 12018

[25] Kandampully, J., \& Suhartanto, D. (2000). Customer loyalty in the hotel industry: the role of customer satisfaction and image. International journal of contemporary hospitality management.

[26] Khan, RU, Salamzadeh, Y., Iqbal, Q., \& Yang, S. (2020). The Impact of Customer Relationship Management and Company Reputation on Customer Loyalty: The Mediating Role of Customer Satisfaction. Journal of Relationship Marketing, 1-27.

[27] Khoo, S., Ha, H., \& McGregor, SL (2017). Service quality and student/customer satisfaction in the private tertiary education sector in Singapore. International Journal of Educational Management.

[28] Klipfel, JAL, Barclay, AC, \& Bockorny, KM 2014. Self-Congruity: A Determinant of Brand Personality. Journal of Marketing Development and Competitiveness.Vol. 8(3)
[29] Koestanto and Tri Yuniati, 2014, Effect of Service Quality on Customer Satisfaction at Bank Jatim Klampis Surabaya Branch, Journal of Management Science \& Research Vol. 3 No. 10 (2014).

[30] Kotler, Philip and Gary Armstrong, 2006, Principles of Marketing, Volume 1, Edition 12, Translation: Bob Sabran, MM, Jakarta: Erlangga

[31] Kotler, Philip and Kevin Lane Keller. 2009. Marketing Management. Edition 12 Volume one. Erlangga: Jakarta

[32] Kotler, and Keller. 2012. Marketing Management. Edition 13. Jakarta: Erlangga

[33] Kumar, A. (2017). Effect of service quality on customer loyalty and the mediating role of customer satisfaction: an empirical investigation for the telecom service industry. Journal of Management Research and Analysis, 4(4), 159-166

[34] Leninkumar, V. (2017). The relationship between customer satisfaction and customer trust on customer loyalty. International Journal of Academic Research in Business and Social Sciences, 7(4), 450-465.

[35] Lovelock, C, and John Wirtz, 2011. "Service Marketing Perspective 7th edition". Jakarta : Erlangga.

[36] Neupane, R., \& Lusiah, L., \& Noviantoro, D. (2018). The Effect of Customer Relationship Marketing (CRM) on Customer Satisfaction: A study on Sound System Service Company. Journal of Marketing Management and Consumer Behavior, 2(3), 15-23.

[37] Devkota, M. (2017). Evaluation of the impacts of service quality dimensions on patient/customer satisfaction: A study of private hospitals in Nepal. International Journal of Social Sciences and Management, 4(3), 165-176

[38] Ndubisi, Nelson O. 2007. "Relationship marketing and Customer loyalty". Marketing Intelligence and Planning. Vol 25. No.1. pg $98-106$.

[39] Ngo, VM, \& Nguyen, HH (2016). The relationship between service quality, customer satisfaction and customer loyalty: An investigation in Vietnamese retail banking sector. Journal of Competitiveness.

[40] Nyadzayo, MW, \& Khajehzadeh, S. (2016). The antecedents of customer loyalty: A moderated mediation model of customer relationship management quality and brand image. Journal of Retailing and Consumer Services, 30262-270. doi:10.1016/j.jretconser.2016.02.002

[41] zkan, P., Süer, S., Keser, . K., \& Kocakoç, . D. (2019). The effect of service quality and customer satisfaction on customer loyalty: The mediation of perceived value of services, corporate image, and corporate reputation. International Journal of Bank Marketing.

[42] Philip Kotler and Kevin Lane Keller, 2012, Marketing Management Thirteenth ed. Volume 2 Translation by BOB Sabran MM : Erlangga Publisher.

[43] Daughter. 2019. "The Influence of Service Quality, Customer Satisfaction and Company Image on Customer Loyalty of PT. Bank Central Asia Tbk Pondok Gede Plaza Branch Office. Journal of Business Management Krisnadwipayana 
[44] Rangkuti, Freddy. 2002. Measuring Customer Satisfaction, Publisher PT Gramedia Pustaka Utama, Jakarta

[45] Saleem, H., \& Raja, NS (2014). The impact of service quality on customer satisfaction, customer loyalty and brand image: Evidence from the hotel industry of Pakistan. Middle-East Journal of Scientific Research, 19(5), 706-711.

[46] Santouridis, I., \& Veraki, A. (2017). Customer relationship management and customer satisfaction: the mediating role of relationship quality. Total Quality Management \& Business Excellence, 28(9-10), 11221133.

[47] Saputro, FG, Sasono, AD, Suyono, J., Elisabeth, DR, \& Bonn, ATB (2020). The Effect of Customer Relationship Marketing and Service Quality on Customer Retention with Customer Satisfaction as A Mediating Variable In Forwarding Companies In Surabaya. IJEBD International Journal Of Entrepreneurship And Business Development eISSN 2597-4785 pISSN 2597-4750, 3(4), 470-478.

[48] Schiffman and Lazar Kanuk, 2000, Customers Behaviorr, International Edition, Prentice Hall

[49] sirgy, Grześkowiak. 2005. Self Concept In Consumer Behavior. A Critical Review Journal OfCustomers Research

[50] Sisca. 2019. Analysis of Factors Affecting Customer Loyalty Through Customer Satisfaction (Study on Indihome Customers in Semarang City). Journal of Management UNDIP

[51] Slack, NJ, \& Singh, G. (2020). The effect of service quality on customer satisfaction and loyalty and the mediating role of customer satisfaction: Supermarkets in Fiji. The TQM Journal.

[52] Sohail, M. Sadiq. 2012. The Antecedents of Relationship Marketing and Customer loyalty: A Conceptual Framework to Determine Outcomes. International Conference on Economics, Business Innovation 38(2012), 236-250. Retrieved from Iacsit Press.

[53] Sugiyono. 2017. Quantitative, Qualitative, and R\&D Research Methods. Bandung : Alfabeta, CV.

[54] Sugiyono. 2016. Research methods Quantitative, Qualitative and R\&D. Bandung: PT Alphabet.

[55] Sunyoto. (2013). Accounting Research Methodology. Bandung: PT Refika

[56] Sutisna, 2003. Consumer Behavior and Marketing Communication, Third Printing. Bandung: PT. Rosdakarya Teens

[57] Tjiptono, 2011, Marketing Strategy. Second edition, Andi publisher, Yogyakarta.

[58] Tjiptono 2009, Marketing Strategy, second edition, seventh printing, Publisher: Andi Offset, Yogyakarta

[59] Winer, R. \& Dhar, R. 2013. Marketing Management. New York: Pearson

[60] Wise. 2018. "The Influence of Service Quality, Brand Equity, Bank Image Mediated by Satisfaction on
Customer Loyalty of Bank Mandiri Mobile Banking Users in Surabaya. Journal of STIE Perbanas.

[61] Windiari, I., \& Djumarno, d. (2021). the effect of service quality, customer relationship marketing, and brand image on customer loyalty and customer satisfaction as an intervening variable. DYNASTY INTERNATIONAL JOURNAL OF eCONOMICS, finance \& Accounting, 1(6), 1048-1059.

[62] Zaidur. 2018. The Effect of Service Quality On Customer Loyalty With Trust And Satisfaction As Mediation Variables. UMM Journal

[63] Zeithaml, Valirie A., \&, Mary Jo. 2009. Service Marketing Integrating Customer Focus Across The Firm. New York: McGraw-Hill Companies. 